УДК 597.08:639.053

В. М. Кочет, О. О. Христов

Дніпропетровський національний університет ім. Олеся Гончара

\title{
ВПЛИВ ПРОМИСЛОВИХ ЕЛЕКТРИЧНИХ ЗНАРЯДЬ ЛОВУ НА ІХТІОФАУНУ ІЗОЛЬОВАНИХ ШТУЧНИХ ВОДОЙМ ДНІПРОПЕТРОВСЬКОЇ ОБЛАСТІ
}

Досліджено вплив промислового електротрала ЕЛУ-4М на іхтіофауну в умовах штучно створених водойм. Наведено порівняльний аналіз матеріалів власних досліджень із літературними джерелами, визначено негативні та позитивні елементи застосування електротрала у процесі промислового вилову риби та регламентацію його застосування. Установлено, що експлуатація промислового електротрала, при всьому його неоднозначному (спірному) впливі на біоту, у штучно створених, ізольованих водоймах, катастрофічно не впливає на їх гідроекосистему. Регламентація роботи трала полягає в обмеженні застосування за сезонами та часу доби, а також-у межах застосування (місцях лову).

В. Н. Кочет, О. А. Христов

Днепропетровский национальный университет им. Олеся Гончара

\section{ВЛИЯНИЕ ПРОМЫШЛЕННЫХ ЭЛЕКТРИЧЕСКИХ ОРУДИЙ ЛОВА НА ИХТИОФАУНУ ИЗОЛИРОВАННЫХ ИСКУССТВЕННЫХ ВОДОЕМОВ ДНЕПРОПЕТРОВСКОЙ ОБЛАСТИ}

\begin{abstract}
Исследовано влияние промышленного електротрала ЭЛУ-4М на ихтиофауну в условиях искусственно созданных водоемов, приведен сравнительный анализ материалов собственных исследований с литературными источниками, определены отрицательные и положительные элементы применения электротрала в процессе промышленного лова рыбы и регламентация его применения. Установлено, что эксплуатация промышленного электротрала, при всем его неоднозначном (спорном) влиянии на биоту, в искусственно созданных, изолированных водоемах, катастрофически не влияет на их гидроэкосистему. Регламентация работы трала заключается в ограничени применения по сезонам и времени суток, а также - в границах применения (местах лова).
\end{abstract}

\author{
V. M. Kochet, O. O. Khristov
}

Oles' Gonchar Dnipropetrovsk National University

\section{INFLUENCE OF INDUSTRIAL ELECTRICAL FISHING GEARS ON ICHTHYOFAUNA IN ISOLATED ARTIFICIAL PONDS OF DNIPROPETROVSK PROVINCE}

The influence of the fishing electrical trawl ELU-4M on ichthyofauna in artificial ponds is studied. The comparative analysis of the results obtained and the literature sources is presented. Negative and positive consequences of the electrical trawl application for industrial fishery and regulation of its use are described. It is determined that the exploitation of the industrial electrical trowl (taking into account some ambiguous influence to the biota) in artificial isolated ponds doesn't influence catastrophically on a hydroecosystem. The work regulation of trowl consists in limitation of its seasonable and diurnal uset, and also in the fishing locations.

(C) В. М. Кочет, О. О. Христов, 2010 


\section{Вступ}

Промисловий електролов, як один зі способів видобутку риби у світовій практиці рибальства, поширився в 1960-ті роки. Широке впровадження даного знаряддя лову зумовлене необхідністю підвищення ефективності вилучення водних живих ресурсів. У процесі теоретичної розробки параметрів електролову та спостереження за дією дослідних і промислових зразків електричних тралів установлено [2;6-12], що комплекс фізіологічних проявів, які спостерігаються у риб при проходженні електричного струму по їх тілу, має характер безумовної оборонної, стосовно подразника, реакції. Ця обставина вигідно відрізняла електричний струм від фізичних засобів впливу (звуку, хімікатів, повітряних завіс тощо) і визначила ефективність його застосування для нових сіткових, безсіткових, безперервних та інших методів лову. Виявлена закономірність лягла в основу розробки різних способів видобутку риби за допомогою впливу на неї електричного струму. Однак зазначені знаряддя викликали й у даний час викликають неоднозначну реакцію в наукових колах, а також у фахівців рибоохоронних і природоохоронних організацій.

Актуальність даної роботи полягає у необхідності розробки заходів зі збереження біологічного різноманіття екосистем (у тому числі - іхтіофауни) на фоні інтенсифікації рибогосподарської діяльності у водоймах регіону в умовах невпорядкованості законодавчої бази щодо процесу експлуатації водних живих ресурсів.

\section{Матеріал і методи досліджень}

Дослідження проведені у період 1996-2009 рр. на акваторії штучно створених малих водойм Дніпропетровської області (Зеленодольська водойма-охолоджувач ТЕС та Південне водосховище), де у промислі застосовується промисловий електротрал ЕЛУ-4М. Здійснене спостереження 150 тралень, проаналізовано 2350 екземплярів риб. Обробка отриманого матеріалу проводилася згідно із загальноприйнятими іхтіологічними методиками $[1 ; 3-5]$. Досліджували реакції риб на вплив електричного струму електротрала: стадії відновлення функцій у часі, стан внутрішніх органів, селективність і ефективність вилучення.

\section{Результати досліджень та їх обговорення}

Основним, стосовно промислового електролову, залишається питання про вплив електричного струму на всі елементи гідробіоти - від нижчих організмів до риб. На початку 1970-х років доведено [7], що основною із трьох фаз впливу (стимуляція, депресія, смерть), найбільш розповсюдженою (переважаючою над іншими) при застосуванні електротрала є стадія депресії. Саме наслідки такого впливу найбільш доцільно й логічно розглянути докладніше.

Оскільки мова йде саме про вплив, навмисно не акцентуємо увагу на ефективності вилучення, хоча дослідження інших спеціалістів [6; 7], а також наші спостереження свідчать про те, що ефективність вилову за допомогою електротрала, зокрема рослиноїдних риб, збільшується у 10-50 разів.

У межах Дніпропетровської області у промислових цілях застосовується електротрал ЕЛУ-4М тільки на двох штучно створених водоймах питного й промислового водопостачання м. Кривій Ріг (Південне водосховище та Зеленодольська водоймаохолоджувач ТЕС). Лов, згідно зі спеціально розробленим режимом рибогосподарської експлуатації, проводиться винятково в осінньо-зимовий період (із жовтня до льодоставу). Проведений аналіз власних даних, а також доступних літературних джерел, дозволяє виділити основні положення. 
1. Насамперед доведеним вважається, що рухливіші риби (із підвищеним рівнем метаболітичного обміну) мають нижчі граничні значення реакцій. Такими у період переважного застосування електротрала у досліджених водосховищах (вересень-січень) $\epsilon$ рослиноїдні риби (товстолобик білий, строкатий, їх гібридна форма). Це перший факт на користь позитивної селективності вилучення даним знаряддям лову видівінтродуцентів. По-друге, нашими дослідженнями підтверджено встановлене в минулому положення [7], що підвищення вікової опірності великих риб придушується зростанням загального струму в їх тілі (через збільшення різниці потенціалів за довжиною тіла). Переважний вплив припадає на старші вікові групи, що також забезпечує селективність при застосуванні електротрала. Таким чином, відбувається вилучення старших вікових груп риб (у даному випадку - крупнорозмірних особин товстолобика) без масштабного захоплювання інших видів у сезон роботи даного знаряддя (жовтеньлистопад). Ця концепція, експериментально доведена ще наприкінці 1960-х років, підтверджується також нашими даними. У контрольних ловах електротралом частка товстолобика за кількістю становить від 75 до 80 \%, а за біомасою - від 90 до $99 \%$.

2. Травмування риб при впливі електротрала найчастіше відбувається не в результаті впливу безпосереднього електричного струму, а при перебуванні риби в зоні поблизу електродного простору, а також при торканні риб до електродів. Однак сама зона цього простору та площа електродів складають невеликий відсоток (до 10 \%) порівняно із зоною опосередкованого впливу полем. Основна кількість риб реагує на вплив електротралом стадією депресії й приспання ще до потрапляння в зону можливого травмування та накопичується в матні трала у неушкодженому стані. У цьому полягає вигідна відмінність електротрала від інших знарядь лову - після настання стадії депресії й приспання травмування риб не відбувається.

3. Найчутливіші на стадії торкання електродів і перебування в електродному просторі хижі риби (судак, щука, окунь). У 30 \% випадків (за нашими даними) контакт 3 електродами закінчується летальним результатом. Відбувається це 3 причин порушення дихальної функції. Хижі оксифільні риби, особливо судак, «оживають» набагато довше (до 3 хв). Перебуваючи у стадії шоку, ці риби не устигають відновити процеси, необхідні для поновлення дихальних функцій.

4. Близько 20 \% молодших вікових і дрібнорозмірних риб, що потрапили в поле дії трала в денний час, але пройшли крізь вічко і потрапили на поверхню, поїдаються чайками, решта встигають піти в нижні шари води. Процентне співвідношення загиблих екземплярів і особин, що пройшли процес релаксації і відновлення життєвих функцій у придонних шарах, із технічних причин установити не можливо. Згідно з упровадженим режимом рибогосподарської експлуатації, крок вічка у кутку електротрала становить не менше 40 мм, у крилах - 70 мм. Таким чином, більшість перших поколінь аборигенних риб електротралом не вилучається.

5. Серед летальних наслідків, як у літературних джерелах, так і за нашими даними, відзначаються окремі функціональні порушення (травми, синці, розриви м'язів і деякі аномалії у складі крові). Інші відзначені порушення у вигляді зниження рухової активності, зміни стадних поведінкових ознак, зміни пігментації тощо - найчастіше цілком відновлюються.

6. Час повного відновлення до норми коропових риб коливається, залежно від виду, розміру тіла та температури води, від декількох десятків секунд до двох годин. Нашими спостереженнями встановлено, що риби молодших вікових груп при вилученні $з$ трала відновлюють активність через 20-30 секунд. Хронометраж «оживання» також показав, що найбільші особини рослиноїдних риб (від 70 см і вище) виходять із 
шоку в період 30-60 с і надалі не виявляють ознак повторного приспання або снулості, а при розміщенні в садках поводяться абсолютно адекватно аж до вилучення (у проведених спостереженнях - до двох тижнів). Факт повного відновлення зазначених функцій не викликає сумнівів і пояснюється механізмом впливу струму на організм риб: основною причиною прояву депресивних функцій у результаті впливу електричного струму є порушення регуляційних механізмів організму, що призводять до тимчасового нервового виснаження, а не до незворотних змін.

7. При роботі електротрала в пелагічній частині досліджених водосховищ в осінньо-зимовий період, прилов, здебільшого, не реєструється або не перевищує $5 \%$ від кількості виловлених риб. Основну масу прилову складають особини вирощуваних (рослиноїдних) видів риб.

8. Особини, вилучені за допомогою електротрала, легше переносять період перебування в садках, ніж вилучені звичайним неводом i, тим більше, сітками. Риби при потраплянні в електротрал під впливом електроструму впадають у стан «наркозу», не доходять до стресового стану, у тому числі гіперактивності і пов'язаних із нею механічних ушкоджень різного ступеня ваги, що може спричинити прискорену елімінацію.

9. 3 проявів, що не спостерігалися у риб інших водойм Дніпропетровської області, відзначена резорбція однієї гонади (у декількох особин ляща; у 1996-2009 рр. установлено 6 таких особин). Однак у основної маси риб обидві гонади розвинуті нормально, а для доказу резорбції як реакції на дію електричного струму електротрала необхідна набагато більша кількість зафіксованих особин із даним відхиленням.

10. Як указувалося вище, Південне водосховище та Зеленодольська водоймаохолоджувач ТЕС не належать до природних водойм. Вони штучно створені як водойми-накопичувачі питної та виробничих вод, тобто функціонують у режимі, що задається людською діяльністю. Рибогосподарське використання цих водойм повинне враховувати весь комплекс діючих факторів і бути спрямованим на максимально ефективне використання продуктивних можливостей цих штучних екосистем, у тому числі за рахунок використання різних способів і типів знарядь лову. Однак така діяльність повинна враховувати комплекс охоронних заходів, спрямованих на збереження біорізноманіття компонентів середовища мешкання.

12. Основний негативний вплив елетротрала - шкода, заподіяна рибам побічно (тим рибам, що піддалися впливові електротрала, але з якихось причин не потрапили до його кутка). Установити кількість загиблих риб від хижаків, у результаті вилучення птахами чи занурення, проблематично. Необхідні спеціальні дослідження із залученням аквалангістів.

13. Проблема впливу електролову на кормові організми вивчена набагато детальніше в силу простоти проведення експериментів і доступності одержання безпосередніх даних під час роботи електротрала. Інформаційний пошук показав, що більшість авторів погоджується з тим, що зі зменшенням розмірів і рівня організації гідробіологічних об'єктів небезпека наслідків зменшується через спрощення або відсутність основного об'єкта впливу - нервової системи. Чисельні значення загибелі зоопланктону й бентосу в результаті дії електролову не були виявлені. Тралення із застосуванням електричного струму, безумовно, впливає на інші об'єкти гідробіоти, однак, оскільки проводиться воно у пізньоосінній і зимовий періоди, після того, як більшість гідробіонтів або припинили існування, або перейшли у фазу зимівлі, установити його вплив на цих тварин не вдалося. У Південному водосховищі трал експлуатується винятково у пелагічній глибоководній зоні, у товщі води. Таким чином, вплив 
на мілководні й придонну глибоководну зони й організми, що там живуть, або мінімальний, або відсутній. Оскільки ступінь впливу на гідробіонтів не встановлений, застосування трала в мілководній зоні на акваторії Південного водосховища було заборонене.

14. Особливо варто підкреслити, що мова йде про промислові трали 3 чітко вивіреними експериментально та закладеними технологічно параметрами струму. Аматорські електроловні пристрої завдають величезної безсумнівної шкоди водним живим ресурсам, оскільки параметри струму, закладені в них, розраховані на ефективність ураження, тобто на летальний результат. Крім того, саморобні електроловні пристрої «електровудки», в основному, застосовуються у прибережній зоні. За нашими спостереженнями, до 70 \% уражених цим знаряддям риб складають малорозмірні особини та молодь. Виходячи 3 доведеної ще в 1960-1970 роки більшої стійкості малорозмірних риб до впливу струму, можна припустити, що значна частина крупнорозмірних риб не вилучається, а гине й залишається на дні водойми.

\section{Висновки}

Короткочасний шоковий стан риб є, головним чином, результатом загального пригнічення периферичної й центральної нервової систем, а не результатом якихнебудь органічних змін інших функціональних систем або тканин. Небезпеку безпосередніх i, тим більше, віддалених наслідків на даному етапі вивченості питання можна вважати недоведеною. Кількісно неясним залишається збиток від загибелі шокованих риб, які не потрапили до трала у результаті поїдання птахами, хижаками або від занурення в мул, до моменту відновлення їх функцій.

Вплив промислового електротрала не може бути ідентифікований як абсолютно негативний і катастрофічний. Його не можна вважати досконально вивченим, що викликає необхідність постійного контролю за його діяльністю. Експлуатація промислового електротрала, при всьому його неоднозначному впливі на біоту, у штучно створених, а також ізольованих водоймах, в обмежених тимчасових рамках і межах застосування (місцях лову), катастрофічно не впливає на гідроекосистему.

Отримані результати свідчать про можливість застосування електротрала на акваторії штучно створених водойм згідно з регламентаціями, викладеними у режимах експлуатації, під регулярним контролем наукових і природоохоронних організацій.

Промисловий електролов рекомендується обмежити штучними водоймами, що не мають повних характеристик природних і орієнтовані на вузькоспрямоване специфічне інтенсивне рибництво, з акцентом на рослиноїдні або інші види-інтродуценти. Безпечне з екологічного погляду застосування елетротрала може бути забезпечене його застосуванням у пелагічній частині цих водойм, винятково в осінньо-зимовий період (із жовтня поточного року до льодоставу, у випадку відсутності льодоставу - до другої декади лютого). Доцільне також застосування трала з вічком не менше 70 мм не тільки в крилах, а й у кутку.

\section{Бібліографічні посилання}

1. Інструкція про порядок спеціального використання риби та інших водних живих ресурсів. Мін-во аграрної політики України, наказ від 11.11.2005 р., № 623/404. - К., 2005. - 18 с.

2. Извеков И. П. Экологическая безопасность електролова рыбы и эффективность промысла во внутренних водоемах / И. П. Извеков, Г. А. Асланов // ВНИЭРХ, ОИ. - 2000. - № 2. - 68 с.

3. Методи гідроекологічних досліджень поверхневих вод / О. М. Арсан, О. А. Давидов, Т. М. Дьяченко та ін. - К. : Ін-т гідробіол. НАНУ, 2006. - 406 с. 
4. Методика збору і обробки іхтіологічних і гідробіологічних матеріалів з метою визначення лімітів промислового вилучення риб із великих водосховищ і лиманів України. - К. : ІРГ УААН, 1998. $-47 \mathrm{c}$.

5. Правдин И. Ф. Руководство по изучению рыб / И. Ф. Правдин. - М. : Пищевая пром-сть, 1966. - 243 c.

6. Христенко Д. С. Використання електротрала ЕЛУ-4М для організації спецлову рослиноїдних риб на водоймі-охолоджувачі Бурштинської ТЕС // Рибне госп-во. - К., 2005. - С. 127.

7. Стернин В. Г. Электролов. Основы теории и практика / В. Г. Стернин, І. В. Никоноров, Ю. К. Бумейстер. - М. : Пищевая пром-сть, 1972. - 223 с.

8. Lamarque P. Electrophysiology of fish in electric fields / P. Lamarque, I. G. Cowx // Fishing with electricity, applications in freshwater fisheries management. Fishing News Books. - Oxford : Blackwell Scientific Publications Ltd. - P. 4-33.

9. Khakimullin A. A. Effect of pulse electric shock on reproductive ability and progeny of Siberian sturgeon, Acipenser baeri (Acipenseridae) / A. A. Khakimullin, N. A. Parfenova // Journal of Ichthyology. - 1984. - Vol. 24. - P. 122-129.

10. Marriott R. A. Effects of electric shocking on fertility of mature pink salmon // Progressive FishCulturist. - 1973. - Vol. 35. - P. 191-194.

11. Snyder D. E. Effects of electrofishing on fish embryos, larvae, and early juveniles // American Fisheries Society Early Life History Section Newsletter. - 1994. - Vol. 15, N 1. - P. 10-13.

12. Vibert R. General report of the working party on the applications of electricity to inland fishery biology and management // R. Vibert (ed.) Fishing with electricity, its application to biology and management. - London : Fishing News (Books) Ltd., 1967. - P. 3-51.

Надійшла до редколегії 23.03.2010 